\title{
Genetic variability of Scots pine (Pinus sylvestris L.) in maternal regions of provenance
}

\author{
Pawet Przybylski $\bowtie$, Jan Matras, Małgorzata Sutkowska \\ Forest Research Institute, Department of Silviculture and Genetics, Sękocin Stary, Braci Leśnej 3, 05-090 Raszyn, Poland, \\ phone: +48 22 7150460, fax: +48 22 7200397, e-mail: P.Przybylski@ibles.waw.pl
}

\section{Abstract}

The analysis of chosen selected Scots Pine (Pinus sylvestris L.), populations representing different seed regions: 107 (Międzyzdroje), 305 (Woziwoda), 206 (Strzałowo), 208 (Białowieża), 504 (Bolesławiec), 606 (Józefów) were performed using 10 isoensyme markers: $G d h$ (E.C.1.4.1.2), $S d h-A, S d h-B$ (E.C.1.1.1.25), $P g d-B$ (E.C.1.1.1.44), $M d h-A$, $M d h-C$ (E.C.1.1.1.37), Got-A, Got-B, Got-C (E.C.2.6.1.1), Dia-C (E.C.1.8.1.4). There were calculated following genetic parameters: allelic frequencies, observed and expected heterozygosities, and Wright's fixation indexes. In populations, the results of analysis indicated presence of rare alleles. In all study populations, the average effective number of alleles per locus was 1.46 and was lower than expected number of alleles per locus of 1.93. The results for the effective number of alleles of the population per locus were as follows: Strzałowo and Białowieża 1.54, Bolesławiec 1.48, Jozefów 1.44, Świnoujście 1.42, Woziwoda 1.35. Average observed heterozygosity in the studied populations was calculated at the level of 0.26 and it was lower than the expected heterozygosity at 0.28 . For populations, the level of heterozygosities were as follow: Strzałowo 0.35, Bolesławiec and Białowieża 0.25, Józefów 0.27, Świnoujście 0.23 , Woziwoda 0.26 . In particular loci level of heterozygosity was different, as the most heterozygous $M d h-C$ locus was estimated, while minimum Got-C.

Significant differences in allele frequency of Hardy-Weinberg deviation equilibrium were found in 10 cases: Strzałowo (Got-C), Bolesławiec (Got-B), Białowieża (Got-B, Gdh), Józefów (Mdh-C), Międzyzdroje (Got-B, Got-C, $M d h-C)$, Woziwoda (Got-C, Gdh). All studied populations had a lower effective number of alleles per locus $\left(\mathrm{N}_{\mathrm{e}}\right)$ comparing to the observed number of alleles $\left(\mathrm{N}_{\mathrm{a}}\right)$. Wright's fixation indices were negative for populations: Strzałowo (-0.09), Józefów (-0.03), Międzyzdroje (-0.01) and positive for: Białowieża (0.12), Woziwoda and Bolesławiec (0.07). The extremely high Wright's fixation index (0.12) was observed for Białowieża population.

\section{KEY WORDS}

genetic diversity, molecular markers, gene pool conservation 


\section{INTRODUCTION}

The Scots pine is particularly widespread species. It is present on both European and Asian continents, and it has the greatest natural range among Pinus species.

Most of the data used as basis in the attempts to describe the genetic variability of the Scots pine indicates that the pine within its compact range is characterized by constant (clinal) variability, and that only isolated populations, such as the Scottish, Spanish, Balkan, Turkish or Caucasian populations display specific traits, not found in the described constant variability. Several attempts at describing Scots pine's genetic variability with a greater scope have been made, e.g. Svoboda (1953) or Molotkov and Patlay (1991). The results however are vastly heterogeneous (Giertych 1980; Przybylski 1970) and the only information that can be used in practice is the population-level data.

The knowledge of variability of a single population is furnished, among others, by provenance research. The first such experiment has been established in 1820 by Vilmorin. Since then, many provenance experiments for the Scots pine have been conducted, most of them in Poland, within the scope of the IUFRO research (Giertych and Oleksyn 1981). Data from provenance research so far, enabled us to distinguish populations characterized by excellent growth and quality traits. The group comprises: Rychtal, Gubin, Bolewice, Dłużek, Lipowa, Jegiel and Milicz. Relatively greater adaptation capabilities - plasticity - is the characteristic of the following populations: Bolewice, Dłużek, Milicz, Czersk, Goleniów, Parciaki, Prószków, Maskulińskie i Suchedniów. A significant level of adaptation to weaker and drier conditions is displayed in the populations of Rychtal, Lipowa and Supraśl, while populations adapted to richer and moister soils are: Jegiel, Janów Lubelski and Spała. In sub-mountainous conditions, in case of lack of own seed base, it is possible to use lowland pine populations of Lipowa, Supraśl, Janów Lubelski and Rozpuda (Matras 1994; Kowalczyk et. al 2000, 2006).

The results of research on Scots pine variability have been used i.a. in seed regionalization determining the rules of using pine's seed base. In the scope of the species' natural range in Poland, 25 maternal regions of provenance have been distinguished. Within a single origin region, only its own seed base may be used. The regions comprise populations that, based on provenance research so far, are characterized by very good growth rate, plasticity and quality. They are, i.a. taborska pine - 106, napiwodzko-ramucka pine - 205, piska pine - 206, augustowska pine - 204, supraślska pine - 207, tucholska pine -305 , bolewicka pine -308 , rychtalska pine -501 , spalska pine -601 , kozienicka pine -602 , parczewska pine -404 , as well as populations of an above average breeding value, growing in areas characterized by poor quality of pines, e.g. łochowska pine -403 , goleniowska pine -101 , and bytowska pine -105 .

There is significantly less information about genetic variability of the pine, based on molecular examination. In terms of genetic variation, the populations from maternal regions have been analyzed by Nowakowska (2007). Nowakowska proved that the highest variation in pine stands exists in the Baltic region, and the lowest - in Silesia, whereas the most homogeneous populations grow in the region of Mazury and Podlasie. Nowakowska's (2007) research confirms the significant impact of human economic activity on the shaping of tree stands, especially in the Silesian and Greater Poland/Pomeranian regions. Nowakowska also described the presence of the " $b$ " haplotype of the nadl gene in Polish populations, a type that is typical for Spanish pine populations. In the light of Prus-Głowacki's et al. research (2012), this could be interpreted as the result of uncontrolled exchanges of seeds in 19th and early 20th centuries. Nowakowska (2007) did not prove any significant genetic diversity between the examined populations; she merely distinguished the Białowieża population as significantly different from the rest. Based on these results, Kowalczyk (2014) formulated a general conclusion, according to which, the nucleic SSR markers are inadequate for genetic variability comparison between populations. This paper attempts to fill in the missing genetic isoenzyme polymorphism information for the majority of the populations examined by Nowakowska (2007).

Isoenzyme polymorphism research has been conducted previously by Krzakowa et al. (1977). It described changes in 12 enzymatic loci in maternal trees and detected heterozygosity of $35 \%$. Polish isoenzyme research has also been conducted by: Mejnartowicz (1979), Mejnartowicz and Bergmann (1985), PrusGłowacki (1982), Prus-Głowacki and Nowak-Bzowy (1992), Prus-Głowacki and Bernard (1994), and Dzialuk and Burczyk (2002 and 2006). Results obtained in these 


\section{DE GRUYTER \\ OPEN}

studies fail to provide a full answer to questions about genetic resources of pine in regions of provenance. That is why the formulated goal of the present research had been the presentation of the variation of the species in maternal regions of provenance: 107 (Międzyzdroje), 305 (Woziwoda), 206 (Strzałowo), 208 (Białowieża), 504 (Bolesławiec) and 606 (Józefów) (fig. 1).

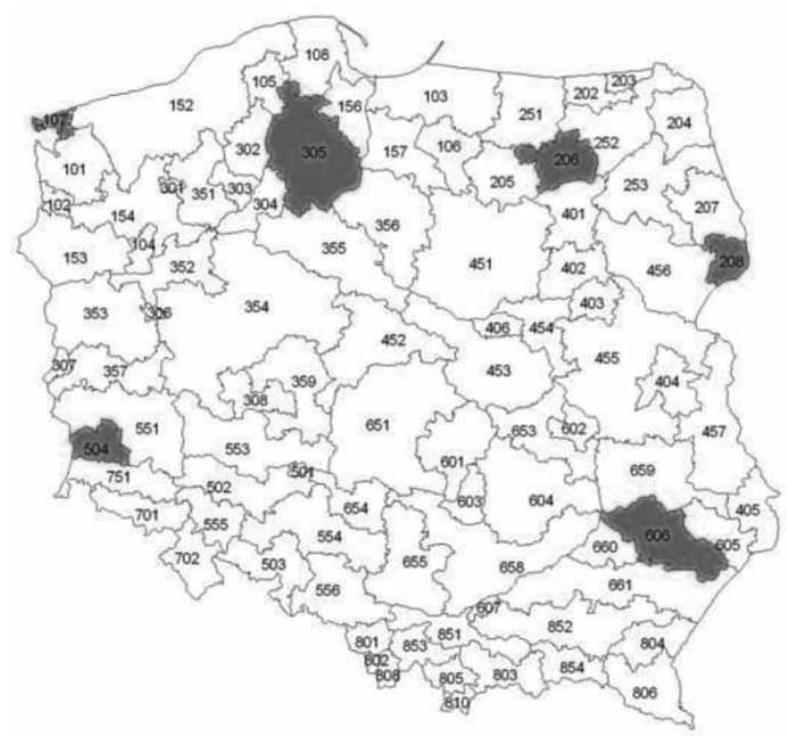

Figure 1. Geographic location of the six selected maternal regions of provenance

\section{Material AND Methods}

The plant material used in the laboratory analysis has been collected in 6 maternal regions of provenance (fig. 1): 107 (Międzyzdroje), 305 (Woziwoda), 206 (Strzałowo), 208 (Białowieża), 504 (Bolesławiec), and 606 (Józefów). Genetic analyses constituted a supplement to project work. In each tree stand, the plant material has been collected from 30 randomly selected, standing trees. Tested trees were at least 30 meters away from the previous tree.

The collected plant material (stems with vegetative buds) has been kept in freezers, at a constant temperature of $-24^{\circ} \mathrm{C}$ until the laboratory analysis. Before commencing electrophoresis, proteins from dormant and coverless vegetative buds have been isolated. The plant material has been homogenized, then extraction of proteins has been performed using $150 \mu$ l of extraction buffer: $100 \mathrm{mM}$ Tris- $\mathrm{HCl} \mathrm{pH} 7.5$ with the additions of 10mM 2-mercaptoethanol and 3 g PVP 25 per $100 \mathrm{ml}$ of the buffer (Cieślewicz 2009). The obtained solution was used to soak strips of Whatman paper (31ET 4 X 11 $\mathrm{mm}$ ) kept in freezers until the analysis.

The electrophoretic separation of proteins has been conducted in 13\% starch gel (Starch-Art), using two buffer systems: A $(184 \mathrm{mM}$ of boric acid, $38 \mathrm{mM}$ of lithium hydroxide as $\mathrm{pH}$ buffer $(\mathrm{pH} 8.3)$ and $46 \mathrm{mM}$ Tris, $7 \mathrm{mM}$ of citric acid, $18 \mathrm{mM}$ of boric acid, $4 \mathrm{mM}$ of lithium hydroxide as gel buffer ( $\mathrm{pH} 8.5))$ and $\mathrm{C}(127$ $\mathrm{mM}$ Tris, $44 \mathrm{mM}$ of citric acid as a $\mathrm{pH}$ buffer $(\mathrm{pH} 7.0)$ and $3.5 \mathrm{mM}$ DL-histidine $\mathrm{HCl}$, brought to $0.5 \mathrm{M}$ Tris to $\mathrm{pH} 7.0$ as pH buffer). Buffers used in the experiment are the same as in the following papers: Odrzykoski (2002) and Cieślewicz (2009).

Upon the completion of electrophoresis, the gel has been cut into layers $1.5 \mathrm{~mm}$ thick. Each of the layers has been then used to visualize the examined isoenzymes. The process has been conducted conforming to Concle et. al (1982) methodology. The following loci have been analyzed: $G d h$ (E.C.1.4.1.2), $S d h-A S d h-B$ (E.C.1.1.1.25), $P g d-B$ (E.C.1.1.1.44), $M d h-A, M d h-C$ (E.C.1.1.1.37), Got-A, Got-B, Got-C (E.C.2.6.1.1), Dia-C (E.C.1.8.1.4). The selected set of allozymes contained variable and monomorphic proteins.

Upon the completion of laboratory analysis, genetic variability parameters of the examined populations have been estimated, using specialized statistics packages: Gen Alex 6.1 (Peakal and Smouse 2006) and PopGen 1.32 (Yeh and Boyle 1997). Genetic variability parameters have been examined, i.a.: average number of alleles per locus $\left(\mathrm{N}_{\mathrm{a}}\right)$, effective number of alleles per locus $\left(\mathrm{N}_{\mathrm{e}}\right)$, observed heterozygosity $\left(\mathrm{H}_{\mathrm{o}}\right)$ ( Nei 1973), expected heterozygosity $\left(\mathrm{H}_{\mathrm{e}}\right)$, as well as the inbreeding coefficient F (Hartl and Clark 2007).

\section{Results}

The results of the conducted research on allele frequency and rare alleles have been presented in table 1 , whereas genetic variability parameters of the examined populations have been presented in table 2 . Figure 2 shows the diversity between various tree stands. Based on the collected data, it has been concluded that there are 28 alleles per population on average, while the av- 
Table 1. Frequency of alleles of studied populations (rare alleles in gray)

\begin{tabular}{|c|c|c|c|c|c|c|c|}
\hline Locus & $\frac{\frac{0}{0}}{\frac{\pi}{2}}$ & 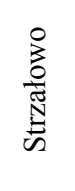 & 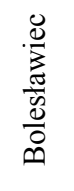 & 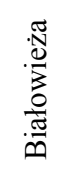 & \begin{tabular}{l}
3 \\
$\stackrel{3}{0}$ \\
\multirow{N}{N}{} \\
0
\end{tabular} & 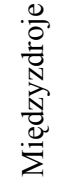 & 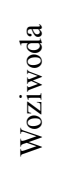 \\
\hline GOT-A & 1 & 0.90 & 0.89 & 0.90 & 0.98 & 0.97 & 0.97 \\
\hline$G O T-A$ & 3 & 0.10 & 0.11 & 0.10 & 0.02 & 0.03 & 0.03 \\
\hline$G O T-B$ & 1 & 0.35 & 0.57 & 0.40 & 0.48 & 0.52 & 0.44 \\
\hline$G O T-B$ & 2 & 0.65 & 0.43 & 0.60 & 0.52 & 0.48 & 0.56 \\
\hline GOT-C & 1 & 0.29 & 0.32 & 0.36 & 0.35 & 0.50 & 0.37 \\
\hline GOT-C & 2 & 0.71 & 0.68 & 0.64 & 0.65 & 0.50 & 0.63 \\
\hline$D I A$ & 1 & 0.65 & 0.84 & 0.77 & 0.91 & 0.94 & 1.00 \\
\hline$D I A$ & 2 & 0.35 & 0.16 & 0.23 & 0.09 & 0.03 & 0.00 \\
\hline$D I A$ & 4 & 0.00 & 0.00 & 0.00 & 0.00 & 0.03 & 0.00 \\
\hline$G D H$ & 1 & 0.54 & 0.32 & 0.48 & 0.40 & 0.54 & 0.44 \\
\hline$G D H$ & 2 & 0.46 & 0.68 & 0.52 & 0.60 & 0.46 & 0.56 \\
\hline$M D H-A$ & 1 & 0.94 & 1.00 & 0.85 & 0.98 & 0.92 & 0.95 \\
\hline$M D H-A$ & 2 & 0.06 & 0.00 & 0.15 & 0.02 & 0.08 & 0.05 \\
\hline$M D H-C$ & 1 & 0.66 & 0.60 & 0.62 & 0.58 & 0.71 & 0.64 \\
\hline$M D H-C$ & 2 & 0.34 & 0.40 & 0.38 & 0.42 & 0.29 & 0.36 \\
\hline$S D H-A$ & 1 & 0.97 & 0.92 & 0.98 & 0.98 & 1.00 & 0.97 \\
\hline$S D H-A$ & 2 & 0.03 & 0.08 & 0.02 & 0.02 & 0.00 & 0.03 \\
\hline$S D H-B$ & 1 & 0.87 & 0.94 & 0.92 & 0.90 & 0.98 & 0.86 \\
\hline$S D H-B$ & 2 & 0.13 & 0.06 & 0.08 & 0.05 & 0.00 & 0.14 \\
\hline$S D H-B$ & 3 & 0.00 & 0.00 & 0.00 & 0.05 & 0.02 & 0.00 \\
\hline$P G D$ & 1 & 0.77 & 0.80 & 0.79 & 0.89 & 0.95 & 0.85 \\
\hline$P G D$ & 2 & 0.23 & 0.18 & 0.21 & 0.11 & 0.05 & 0.15 \\
\hline$P G D$ & 4 & 0.00 & 0.02 & 0.00 & 0.00 & 0.00 & 0.00 \\
\hline
\end{tabular}

erage quantity of alleles in a locus equals 1.98. Populations differ between one another in allele frequency. Statistically significant differences in allele frequency have been stated in 10 populations: Strzałowo $($ Got-C), Bolesławiec (Got-B), Białowieża (Got-B, Gdh), Józefów $(M d h-C)$, Międzyzdroje (Got-B, Got-C, Mdh-C), and Woziwoda (Got-C, Gdh). The remaining alleles showed no significant differences. By analyzing the significantly different alleles, it has been observed that the following alleles are dominant for their respective population(s):
Strzałowo Got-C-2, (71\%), Bolesławiec Got-B-1, (57\%), Białowieża Got-B-2 (60\%) and Gdh- $2(52 \%)$, Józefów $M d h-C-1$ (58\%) i Mdh-C-1 (71\%), Woziwoda Got-C-2 (63\%) and Gdh-2 (55\%), Międzyzdroje Got-B-1 (51\%), while Got-C-1 and Got-C-2 had an equal frequency of $(50 \%)$ (see tab. 1).

Table 2. Effective number of alleles per locus (Ne), heterozygosity: expected $(\mathrm{He})$ and observed (Ho), inbreeding coefficient $(\mathrm{F})$ in examined populations

\begin{tabular}{|l|c|c|c|c|c|}
\hline & & $\mathrm{Ne}$ & $\mathrm{Ho}$ & $\mathrm{He}$ & $\mathrm{F}$ \\
\hline \multirow{2}{*}{ Strzałowo } & & 1.54 & 0.35 & 0.32 & -0.09 \\
\cline { 2 - 6 } & $\mathrm{SE}$ & 0.11 & 0.07 & 0.05 & 0.09 \\
\hline \multirow{2}{*}{ Bolesławiec } & & 1.48 & 0.26 & 0.29 & 0.07 \\
\cline { 2 - 6 } & $\mathrm{SE}$ & 0.11 & 0.05 & 0.05 & 0.07 \\
\hline \multirow{3}{*}{ Białowieża } & & 1.55 & 0.25 & 0.32 & 0.12 \\
\cline { 2 - 6 } & $\mathrm{SE}$ & 0.11 & 0.03 & 0.05 & 0.07 \\
\hline \multirow{2}{*}{ Józefów } & & 1.45 & 0.27 & 0.26 & -0.04 \\
\cline { 2 - 6 } & $\mathrm{SE}$ & 0.13 & 0.08 & 0.06 & 0.07 \\
\hline \multirow{2}{*}{ Międzyzdroje } & & 1.42 & 0.23 & 0.24 & -0.02 \\
\cline { 2 - 6 } & $\mathrm{SE}$ & 0.14 & 0.07 & 0.07 & 0.08 \\
\hline \multirow{2}{*}{ Woziwoda } & & 1.36 & 0.22 & 0.26 & 0.07 \\
\cline { 2 - 6 } & $\mathrm{SE}$ & 0.19 & 0.05 & 0.06 & 0.07 \\
\hline
\end{tabular}

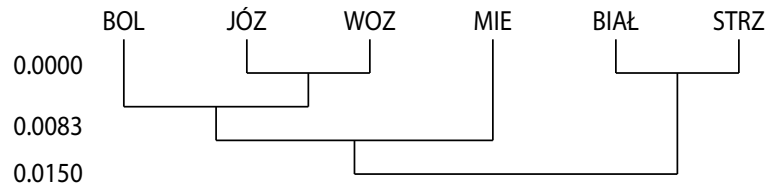

Figure 2. Dendrogram of genetic distance, according to Nei (1987) of studied populations

Rare alleles (frequency below 5\%) have been found in all examined populations. The frequency of rare alleles has usually oscillated between 1.6 to $3.2 \%$. Allele 2 in the $S d h-A$ locus has been the most common rare allele in the examined populations. Its presence has been detected in: Strzałowo, Białowieża, Józefów and Woziwoda. Rare alleles that could constitute population markers have also been described. Among them is the diaphoresis allele 4, present exclusively in the Międzyzdroje tree stand.

In the analyzed tree stands, the average effective number of alleles per locus amounted to 1.46 and had 


\section{DE GRUYTER}

been inferior to the expected per locus allele quantity of 1.93. Specific populations, the effective number of alleles per locus has been: 1.54 in Strzałowo and Białowieża, 1.48 in Bolesławiec, 1.44 in Józefów, 1.42 in Międzyzdroje and 1.35 in Woziwoda (tab. 2).

Average observed heterozygosity in examined populations equalled 0.26 and was inferior to expected heterozygosity by 0.02 . Specific populations had the following values of heterozygosity: Strzałowo 0.35, Bolesławiec and Białowieża 0.25, Józefów 0.27, Międzyzdroje 0.23 , Woziwoda 0.26 . Specific loci had different levels of heterozygosity, the highest noted in $M d h-C$, and the lowest - Got-C (tab. 2).

The estimated level of inbreeding has divided the examined populations into two groups - one, where the F coefficient was positive, and the other, where it was negative. The first group comprises the populations of: Białowieża (0.12), Woziwoda (0.07) and Bolesławiec (0.07), the other: Strzałowo $(-0.09)$, Józefów $(-0.03)$ and Międzyzdroje $(-0.01)$. In the six examined populations, the genetic differentiation coefficient (Nei 1973) equalled $7.7 \%$.

In order to determine the genetic differentiation, genetic distances between the examined populations have been calculated. The dendrogram divided the populations into two groups (fig. 2). The first group included the Białowieża and Strzałowo populations, the remaining four populations constituted the other group. Two populations are the most similar to one another, based on Nei's (1973) genetic differentiation coefficient, namely Woziwoda and Józefów. Their genetic distance equals 0.0032 . Międzyzdroje however, is the population with the greatest genetic distance in the second subgroup, namely 0.0094 .

Through analysis of genetic variability parameters, the examined populations have been divided into two sub-groups, based on their inbreeding coefficient $F_{\text {is }}$. The first subgroup comprises populations with a greater heterozygosity, than the expected one, according to Hardy Weinberg law: Międzyzdroje, Strzałowo and Józefów. The second subgroup contains populations where homozygotes are dominant: Białowieża, Woziwoda and Bolesławiec. Particular attention has been granted the Białowieża population, whose inbreeding coefficient $F_{\text {is }}$ equals 0.12 . The high value of inbreeding in Białowieża results from homozygosity of two loci: Got-B and $G d h$.

\section{Discussion}

In 2000, in Poland, the boundaries of regions of provenance of basic reproduction material (Forest Reproductive Material - FRM) for 10 forest-forming tree species have been established. These regions have been created on the basis of ecological differentiation, based on forest regionalization, as well as information obtained from provenance and genetic research (Matras 1996; Resolution of the Minister of Environment of 9th March 2004; Nowakowska and Rakowski 2005). Originally, the region boundaries have been established on the basis of observed phenotypic traits in examined tree populations (Matras 2005; Matras et al. 1993; Nowakowska and Rakowski 2005). It is therefore important to determine the true genetic variability of seed regions in Poland, based on actual genetic research.

Forest trees belong to the most variable organisms in nature. It is in part due to the size of their genome. For example, the pine comprises about 50 billions nucleotide pairs (Paule 1992). It has also been observed that generations of trees may pollinate one another, which makes it all the more difficult to determine genetic differentiation of the population. As a consequence, it is possible for pine populations that are very remote geographically and different phenotypically to display close genetic resemblance (Krzakowa 1979; Matras 2005).

Scots pine diversity in Poland is clinal, and its main source is the inter-population variability. Nowakowska and Rakowski (2005) and Nowakowska (2007) indicate that as much as $70 \%$ of genetic variability of Scots pine is due to inter-population variability. This is also corroborated by the present study, in which all analyzed populations have been characterized by a greater inter-population diversity, than between populations $\left(\mathrm{F}_{\mathrm{st}}=0.077\right)$. It is therefore justified to put forth a general thesis that it is crucial for forestry to preserve economically valuable tree stands, as they most likely contain the unique gene sets for their respective areas.

The average allele quantity per locus in the present research has been determined at 1.98. This result is significantly lower than in Prus-Głowacki and Bernard's research of 1994, or in those of Samoćko (2004) and Dzialuk et al. (2006). The lower allele quantity per locus is most likely due to using a set of less polymorphic loci, than in the abovementioned publications. 
In the present work, the populations with the greatest allele quantity per locus were: Białowieża and Strzałowo. These populations are characterized by a high heterozygosity coefficient. In addition, tree stands from Strzałowo and Białowieża constitute a separate group on the dendrogram, which is indicative of their genetic autonomy. This result could suggest their indigenousness. Based on the results, it could be deduced with high probability of success that the influence of uncontrolled seed exchanges on the genetic structure of Białowieża and Strzałowo populations has been insignificant. Results of other research, i.a. that of Nowakowska (2007) and historic information indicate that Polish tree stands, especially in the Prussian territory from the Partition era in the 19th century have been over-exploited. Seeds for forestation purposes have been obtained from various, often situated far from places of origin. The present research confirms the influence of over-exploitation of tree stands in western Poland, which is consistent with earlier research. The Międzyzdroje population is particularly interesting, where diaphoresis allele 4 and Phosphoglucoisomerase allele 4 have been found. These are rare alleles, and in the scope of the present research, they have only been found in this population. It is supposed that these proteins could be a trace of dominant alleles in a different climatic region, which constitutes proof of the foreign origin of the seeds, from which the examined tree stand has been bred.

To sum up, it is interesting to note that genetic variability of Scots pine in Poland, based on isoenzyme research has for the most part confirmed the results of other molecular research and breeding experiments. It is therefore correct to assume that the distinction of seed regions and other actions aiming to preserve their gene resources are fully justified.

\section{Conclusions}

1. Molecular research using isoenzyme markers has confirmed the diversity of Scots pine, based on breeding traits and the fact of significantly higher intra-population genetic variability within the species.

2. Two of the examined populations: Strzałowo and Białowieża are characterized by an individual and distinct genetic structure, which is was shown on dendrogram configuration and the highest value effective number of alleles values. For this reason, they should be the first to be included in Scots pine genetic variability protection programs, executed by Polish State Forests National Forest Holding.

3. Rare forms of unique alleles found for Scots pine populations of West Poland e.g. from Międzyzdroje can confirm the influence of forest over-exploitation and uncontrolled seed exchanges of the 19th century in western Poland.

\section{References}

Bergmann F., Gregorius H.R., Larsen J.B. 1990. Levels of genetic variation in Europen silver fir (Abies alba). Genetica, 82, 1-10.

Białobok W.S., Boratyński A., Bugała W. 1993. Biologia sosny zwyczajnej. Sorus, Poznań.

Cieślewicz A. 2009. Charakterystyka wybranych loci mikrosatelitarnych u sosny zwyczajnej i ich wykorzystanie do identyfikacji szczepów drzew matecznych. Doctoral dissertation. Adam Mickiewicz University, manuscript.

Concle M.T., Hodgskiss P.D., Nunnaly L.B., Hunter S.C. 1982. Sterch gel electrophpresis of conifer seeds, a laboratory manual. USDA Forest Service. Pacific Southwest Forest and Range Experimental Station. General Technical Report PSW, 64, 18.

Dzialuk A., Burczyk J. 2002. Comparison of genetic diversity of Scots pine (Pinus sylvestris L.) from qualified seed-tree stand and clonal seed orchard. Ecological Questions, 2, 89-94.

Dzialuk A., Burczyk J. 2006. Zmiany struktury genetycznej pomiędzy populacja rodzicielską a potomną w drzewostanie nasiennym sosny zwyczajnej (Pinus sylvestris L.). Sylwan, 10, 30-38.

Giertych M. 1980. Polskie rasy sosny, świerka i modrzewia w międzynarodowych doświadczeniach proweniencyjnych. Arboretum Kórnickie, 25, 135-160.

Giertych M., Oleksyn J. 1981. Summary of results on Scots pine (Pinus silvestris L.) on volume production in Ogevskij's pre-revolutionary Russian provenance experiments. Silvae Genetica, 30 (2), 50-74.

Hartl D.L., Clark A.G. 2007. Podstawy genetyki populacyjnej. Wydawnictwo Uniwersytetu Warszawskiego, Warsaw. 


\section{DE GRUYTER}

Kosińska J., Lewandowski A., Chałupka W. 2007. Genetic variability of Scots pine maternal populations and their progenies. Silva Fennica, 41 (1), 5-12.

Kowalczyk J. 2013. Międzypokoleniowa zmienność struktury genetycznej wybranych drzewostanów sosny zwyczajnej (Pinus sylvestris L.). Prace IBL, Rozprawy i Monografie, 19, 7-136.

Kowalczyk J., Matras J., Korczyk A.F., Sabor J., Barzdajn W., Żybura H., Matras J. 1994. Zmienność sosny pospolitej i hodowlana wartość jej proweniencji. IBL, Warsaw.

Kowalczyk J., Matras J., Żybura H., Sabor H., Barzdajn W. 2000. Zmienność sosny pospolitej i hodowlana wartość jej proweniencji. IBL, Warsaw.

Krzakowa M. 1979. Enzymatyczna zmienność międzypopulacyjna sosny zwyczajnej (Pinus sylvestris L.). Adam Mickiewicz University Press, Poznań.

Krzakowa M., Szweykowski J., Korczyk A. 1977. Population genetics of Scots pine (Pinus sylvestris L.) forests. Genetic structure of plus-trees in Bolewice near Poznań (West Poland). Bulletin of the Polish Academy of Sciences. Biological Sciences, 25, 583-590.

Lindgren D., Gregorius H.R. 1976. Inbreeding and coancestry. In: Proceedings of the IUFRO joint meeting on advanced generation breeding. Bordeaux, France.

Marshall D.R., Brown A.H.D. 1975. Optimum sampling strategies in genetic conservation. In: Crop genetic resources for today and tomorrow (eds.: O.H. Frankel, J.G. Hawkes), Cambridge University Press, Cambridge.

Matras J. 1996. Rejestr drzew doborowych, plantacji i plantacyjnych upraw nasiennych. DGLP, IBL, Warsaw.

Matras J. 2005. Ochrona leśnych zasobów genowych i ich wykorzystanie w selekcji drzew oraz nasiennictwie i szkółkarstwie leśnym. Międzynarodowa konferencja - naukowo techniczna - Ochrona leśnych zasobów genowych i hodowla selekcyjna drzew leśnych w Polsce - stan i perspektywy. Malinówka, June 2005, 5-15.

Matras J., Burzyński G., Czart J., Fonder W., Korczyk A., Puchniarski T., Tomczyk A., Załęski A. 1993. Program zachowania leśnych zasobów genowych i hodowli selekcyjnej drzew leśnych w Polsce. State
Forests National Forest Holding, Forest Research Institute, Warsaw.

Mejnartowicz L. 1979. Genetic variation in some isoenzyme loci in Scots pine (Pinus sylvestris L.) populations. Arboretum Kórnickie, 24, 91-104.

Mejnartowicz L. 1999. Ochrona zmienności i różnorodności genetycznej szczątkowych popualcji Abies alba w Sudetach. Stan i perspektywy badań z zakresu hodowli lasu. 1st Forest Conference materials. IBL, Sękocin Las, 18-19 May, 121-124.

Mejnartowicz L., Bergmann F. 1985. Genetic differentiation among Scots pine populations from the lowlands and the mountains in Poland. Lecture Notes in Biomathematics, 60, 253-266.

Molotkov P.T., Patlai I.N. 1991. Systematic position within the genus and intraspecific taxonomy. In: Genetic of Scots pine (eds.: M. Giertych, M. Csaba), Akademiai Kiado, Budapest, 23-86.

Nei M. 1973. Analysis of gene diversity in subdivided populations. Proceedings of the National Academy of Sciences USA, 70, 3321-3323.

Nowakowska J. 2007. Zmienność genetyczna polskich wybranych populacji sosny zwyczajnej (Pinus sylvestris L.) na podstawie analiz polimorfizmu DNA. IBL, Sękocin Stary.

Nowakowska J., Rakowski K. 2005. Charakterystyka zmienności genetycznej sosny napiwodzko-ramuckiej i spalskiej na podstawie analiz mitochondrialnego DNA. Leśne Prace Badawcze, 2, 73-91.

Odrzykoski I.J. 2002. Badania nad zmiennością genetyczną kosodrzewiny (Pinus mugo) z wykorzystaniem markerów biochemicznych i molekularnych. Adam Mickiewicz University Press, Poznań.

Paule L. 1992. Genetika a slachtenie lesnych drevin. Priroda, Bratislava.

Peakall R., Smouse P. 2006. GenAlex 6: Genetic Analysis in Excel. Population genetic software for teaching and research. Molecular Ecology Notes, 6, 288-295.

Prus-Głowacki W. 1982. Badania nad zmiennością genetyczną w klasach wiekowych naturalnie odnawiającej się populacji sosny (Pinus sylvestris L.). Adam Mickewicz University Press, Poznań.

Prus-Głowacki W., Urbaniak L., Bujas E., Curtu A.L. 2012. Genetic variation of isolated and peripheral populations of Pinus sylvestris L. from glacial refugia. Flora, 207 (2), 150-158. 
Prus-Głowacki W., Bernard E. 1994. Allozyme variation in population of Pinus sylvestris L. from a 1912 provenance trial in Pulawy (Poland) populations. Silvae Genetica, 43, 132-138.

Prus-Głowacki W., Nowak-Bzowy R. 1992. Genetic structure of natural regenerating Scots pine population tolerant for hight pollution near a zink smelter. Water, Air and Soil Pollution, 62, 249-259.

Przybylski T. 1970. Zmienność sosny zwyczajnej (Pinus silvestris L.) polskich proweniencji. Zakład Dendrologii i Arboretum Kórnickie PAN, Kórnik.

Regulation by the Minister of Environment of 9 March 2004 on charts, areas and maps of regions of ori- gin of basic forest reproductive material. Journal of Laws no. 67, pos. 621.

Samoćko J. 2004. Zmienność genetyczna drzewostanu sosny zwyczajnej (Pinus sylvestris L.) i jego potomstwa. Doctoral dissertation ID PAN Kórnik. Manuscript.

Svoboda P. 1953. Lesni dřeviny a jejich porosty. Cast 1 . Statni zemedelske nakladatelstvi, Praha.

Vidakovic M. 1991. Conifers morphology and variation. Grafićki zavod Hrvatske, Zagreb.

Yeh F.C., Boyle T.J.B. 1997. Population genetic analysis of co-dominant and dominant markers and quantitative traits. Belgian Journal of Botany, 129, 157-163. 